\title{
THE RegUlatory TURN IN IP
}

\author{
MARK A. LEMLEY*
}

History shows technologies flourish where market entry is free. ${ }^{1}$ If people are free to come up with a new idea, completely different than anything done before, and launch it into the marketplace, society benefits, people make a lot of money, and we change the world.

So we don't want a "Mother, may I?" regulatory regime for innovation. A regulatory regime that requires permission to enter the market or develop a new product is a problem for innovation because it relies on the government, not the innovator, to decide the course of innovation.

Nor should we give a private company or individual "Mother, may I?" control over market entry. We are right to worry about government restrictions on entry. But we should also worry about incumbents, who can and will have an incentive to impose similar restrictions. It is important to remember, because it is quite often lost in the rhetoric surrounding these debates, that it is not the case that individual private decisionmaking is necessarily efficient. It is the case, however, that market decisionmaking is generally efficient. ${ }^{2}$ But market decisionmaking is efficient largely because when stupid, greedy, or shortsighted people in the private sector make poor

\footnotetext{
(C) 2012 Mark A. Lemley.

* Mark A. Lemley is the William H. Neukom Professor of Law at Stanford Law School. He is also a founding partner of Durie Tangri LLP.

This essay was adapted from panel remarks given at the 2012 Federalist Society Annual Student Symposium held March 3, 2012, at Stanford Law School in Palo Alto, California. For an audio and video recording of the complete panel, please visit the Federalist Society's website. Technology and Regulation, THE FEDERALIST SOCIETY, http://www.fed-soc.org/publications/detail/technology-and-regulationevent-audiovideo (last visited Oct. 31, 2012). Thanks to Rose Hagan for comments on an earlier draft.

1. See generally William J. Baumol, The Free-Market Innovation Machine (2002).

2. See Mark A. Lemley, Property, Intellectual Property, and Free Riding, 83 TEX. L. REV. 1031, 1041 (2005); see also R. H. Coase, The Problem of Social Cost, 3 J. L. \& ECON. 7, 8 (1960).
} 
decisions, they are overthrown by people who make correct decisions. For private decisionmaking to produce efficient decisions, there must be a competitive market. In a "Mother, may I?" regulatory regime, whether government-imposed or incumbent-imposed, that competitive market will not exist and private decision making will not be efficient. Instead, a single private company (or the government) would make decisions for all participants. Unconstrained by market forces, such a private company is no more likely to perform well than government regulators.

Is intellectual property (IP) a "Mother, may I?" regime? The answer is complex. One way to view IP - the way Richard Epstein does-is to say: IP is a property regime; it is something around which parties can freely contract. ${ }^{3}$ To libertarians, property regimes are good, so if IP rights are property regimes, more IP is better. But another way to view IP rights is to say, "this is a government restriction on what people can do with their own physical property and their own ideas." To libertarians, government restrictions on what people can do in a marketplace are bad, and so libertarians ought to think IP rights are bad. ${ }^{4}$ The problem is that IP is both. It is at once a basis around which we can contract and allow the spread of new ideas and a government regulatory intervention in the marketplace that is designed to restrict what people can do with their own ideas and their own property.

If the idea of IP has this dual character, so too does IP law. In both copyright and patent in the last few years, maybe in the last few decades, we have seen a turn increasingly towards the regulatory side of IP and away from freedom of contract. The IP statutes contain some evidence of this change. The Copyright Act is almost ten times longer today than it was before it was amended in $1976 .{ }^{5}$ Large swathes of the Copyright Act really are regula-

3. See Richard A. Epstein, The Disintegration of Intellectual Property? A Classical Liberal Response to a Premature Obituary, 62 STAN. L. REV. 455, 480-513 (2010).

4. For a survey of the competing libertarian interests in intellectual property, see N. Stephan Kinsella, Against Intellectual Property, J. LIBERTARIAN STUD., Spring 2001, at $1,8-12$.

5. Compare Copyright Act of 1909, Pub. L. No. 60-349, 35 Stat. 1075, available at http://www.copyright.gov/history/1909act.pdf (23 pages in typed, nonproportional font), with Copyright Act and related amendments, UNITED STATES COPYRIGHT OFFICE, COPYRIGHT LAW OF THE UNITED STATES AND RELATED LAWS CONTAINED IN TITLE 17 OF THE UNITED STATES CODE (2011), available at http://www.copyright.gov/title17/circ92.pdf (266 pages). 
tion: regulating price, setting compulsory licenses, determining what can be done, etc. ${ }^{6}$ The Patent Act is also moving in the same direction. Historically, most of the main provisions of the Patent Act were common law oriented. ${ }^{7}$ As Richard Epstein has suggested, the new patent statute is definitely a step towards a regulatory rather than a common law regime. ${ }^{8}$

This regulatory turn in IP is not only evident in the statutory frameworks but also in the application of the law. In copyright law, after about fifteen years in which the government more or less left the Internet alone, copyright owners are making greater efforts to get the government to regulate what people can do online. Copyright owners are rightly concerned that there is a lot of copyright infringement online, but the new efforts are troubling. Some of these efforts take the form of lawsuits against Internet intermediaries, ${ }^{9}$ search engines, ${ }^{10}$ credit card companies, ${ }^{11}$ venture capitalists, ${ }^{12}$ and indeed anyone and everyone who can be connected in some way with the distribution of copyrighted content online. Not all of these cases are private civil suits; the government has also prosecuted Internet intermediaries like MegaUpload. ${ }^{13}$ Copyright owners have engaged in a flurry of efforts (some successful, some not) to pass new laws targeting copyright infringement online, whether by

6. See, e.g., 17 U.S.C. §§ 108, 110-11, 113-15, 118-19, 121-22 (2006).

7. See Peter S. Menell, Forty Years of Wondering in the Wilderness and No Closer to the Promised Land: Bilski's Superficial Textualism and the Missed Opportunity to Return Patent Law to Its Technology Mooring, 63 STAN. L. REV. 1289, 1308-11 (2011) (describing the historical interpretation of the Patent Act and recent departure).

8. See Richard A. Epstein, Patent Deformation: US Congress Sails Into Dangerous Waters, FINANCIAL TIMES, Apr. 26, 2011, http://www.ft.com/cms/s/0/27d02b1c6f8d-11e0-952c-00144feabdc0.html.

9. See, e.g., Viacom Intern., Inc. v. YouTube, 676 F.3d 19 (2d Cir. 2012); UMG Recordings, Inc. v. Shelter Capital Partners LLC, 667 F.3d 1022 (9th Cir. 2011); ValCom Sues Megaupload.com for Copyright Infringement, PR NEWSWIRE, (Mar. 23, 2012), http://www.prnewswire.com/news-releases-test/valcom-sues-megaupload com-for-copyright-infringement143977406.html?utm_expid=43414375-18.

10. See, e.g., Perfect 10, Inc. v. Amazon.com, Inc., 508 F.3d 1146 (9th Cir. 2007).

11. See, e.g., Perfect 10, Inc. v. Visa Int'l Serv., Assoc., 494 F.3d 788 (9th Cir. 2007).

12. See, e.g., In re Napster, Inc. Copyright Litigation, 462 F. Supp. 2d 1060 (N.D. Cal. 2006) (including venture capital firm Hummer Winblad as party).

13. See Ben Sisario, U.S. Charges Popular Site With Piracy, N.Y. TIMES, Jan. 20, 2012, at B1. 
raising the penalties for enforcement ${ }^{14}$ or by giving entirely new enforcement powers to courts. ${ }^{15}$

More obviously regulatory is legislation pushing technology mandates - for instance, legislation that says a website is permissible (or a TV signal accepted) only if it includes certain types of filtering technologies to filter improper material. This marks a move away from a regime in which people are free to put what they want on the Internet and towards a regime in which the government or the content owners control ex ante what others can do with their technology.

Most troubling, the government has increasingly started deciding whether or not individuals can put up their websites at all rather than just helping private parties sue for copyright infringement. In the last two years, the United States government has seized and shut down roughly 750 Internet domain names (and all of the speech contained thereon) without ever holding an adversarial hearing or obtaining a court order stating that there is any copyright infringement on those sites, much less that the entire site infringes copyright. ${ }^{16}$ These sites were suddenly put out of business because the government decided the website content was not appropriate. In the few cases in which domain name owners have tried to get their domains back, they have faced endless delays and bureaucratic shuffling, even when it seems obvious that the government made a mistake in seizing the domain name. ${ }^{17}$ That is one of the hallmarks of regulation and a "Mother, may I?" regime.

Patent law has undergone its own regulatory turn, though outside of pharmaceuticals the role of the government in enforcing it is less direct. The goal of the patent system is to en-

14. See, e.g., Prioritizing Resources and Organization for Intellectual Property Act of 2008, Pub. L. No. 110-403, § 104, 122 Stat. 4256, 4259 (increasing civil penalties for counterfeiting that violates copyright law).

15. See, e.g., Stop Online Piracy Act, H.R. 3261, 112th Cong. § 102 (2011) (proposing granting courts the authority to block Internet access to sites that facilitate copyright violations upon application from the Department of Justice).

16. David Kravets, Uncle Sam: If It Ends in .Com, It's .Seizable, WIRED (Mar. 6, 2012, 6:30 AM), http://www.wired.com/threatlevel/2012/03/feds-seize-foreign-sites/.

17. See, e.g., Ben Sisario, Hip-Hop Copyright Case Had Little Explanation, N.Y. TIMES, May 7, 2012, at B4; Ryan Singel, Oops! Copyright Cops Return Seized RojaDirect Domain Names - 19 Months Later, WIRED (Aug. 29, 2012, 4:07 PM), http://www.wired.com/threatlevel/2012/08/domain-names-returned/ (government withdrew its seizure complaint and returned the rojadirecta.com domain name 19 months after it was seized, while a motion to dismiss its complaint was pending). 
courage innovation by giving innovators economic rewards. ${ }^{18}$ It is worrying that our fastest-developing, most innovative industries, the ones that are generating the most new innovations and the most money, by and large hate patents. ${ }^{19}$ They view patents as a tax and a cost of innovation, not as a benefit to innovation. ${ }^{20}$ This is largely because these industries are happy innovating in a world in which they are unrestricted by the law. They don't need government approval to launch a new app, game, or phone. Their interaction with patent law is generally when it limits what they can do, not when it opens up an innovative opportunity.

In the information technology and software industries, which produce up to half of all patents ${ }^{21}$ and file most patent lawsuits, ${ }^{22}$ the most innovative companies say patents are largely a problem, not an opportunity. Most often, patent plaintiffs in those industries are either people who are not in the market at all, the so-called "patent trolls," 23 or people who are losing market share, such as Yahoo, asserting patents against Facebook and demanding royalties. ${ }^{24}$ The smartphone patent wars are one notable exception; ${ }^{25}$ they do involve innovative companies suing their competitors and trying to keep them out of the market. Even in that instance, however, the most likely outcome is not innovators benefiting in terms of

18. See Lemley, supra note 2 , at 1031.

19. See Larry Popelka, Only Lawyers Win in Patent Wars, BLOOMBERG BUSINESSWEEK, Apr. 24, 2012, http://www.businessweek.com/articles/2012-0424/patent-wars-lawyers-are-the-only-winners ("A patent arms race is on. It is likely to hurt-not help-real innovation.").

20. See id. ("[P]atents have simply become a tax on innovation, a necessary evil for defensive purposes ....").

21. See Mark A. Lemley \& Bhaven Sampat, Is the Patent Office a Rubber Stamp?, 58 EMORY L.J. 181, 195 (2008).

22. See John R. Allison et al., Extreme Value or Trolls on Top?: The Characteristics of the Most-Litigated Patents, 158 U. PA. L. REV. 1, 18 (2009).

23. For a discussion of the costs imposed by litigation from non-practicing entities-commonly referred to as "patent trolls" - see James Bessen \& Michael J. Meurer, The Direct Costs from NPE Disputes (Bos. Univ. School of Law, Working Paper No. 12-34, 2012), available at http://papers.ssrn.com/sol3/papers.cfm? abstract_id=2091210.

24. Since I gave this talk, Yahoo and Facebook resolved their litigation. See Michael J. De La Merced, Yahoo and Facebook Settle a Lawsuit Over Patents, N.Y. TIMES, July 7, 2012, at B2. For the initial report, see Barbara Ortutay, Yahoo Sues Facebook over patents, USA TODAY, Mar. 13, 2012, at 1B.

25. See Ashby Jones and Jessica E. Vascellaro, Smartphone Patents: The NeverEnding War, WALL ST. J., Apr. 13, 2012, at B1, available at http://online.wsj.com/ article/SB10001424052702303624004577339931560320116.html. 
market share, but innovators on both sides having to sit down and work out a cross-license because there are so many patents at stake that no company can make a smartphone without infringing someone else's patent. So far, companies have spent upwards of $\$ 15$ billion purchasing patents and hiring lawyers to jockey for position in that ultimate cross-license. ${ }^{26}$ The cumulative effect of the patent system in the internet technology industries is to create a regime where innovation requires not just one permission, but many. Large technology companies may be able to afford the price of those permissions, but pity the poor start-up who wants to enter this market. It will find it has many "mothers" from whom it must seek permission. ${ }^{27}$

There are other industries that really do need strong patent protection, such as the pharmaceutical and the biotechnology industries. ${ }^{28}$ But strong patent protection in the life sciences is required because they are already regulated industries. In the pharmaceutical industry the government requires perhaps ten years of safety and efficacy review, costing hundreds of millions of dollars in research, development, testing, and marketing, before allowing the launch of a pharmaceutical product. ${ }^{29}$ Those companies have to be able to recover their huge investment or they simply will not bother to develop a new drug. ${ }^{30}$ How do they get that investment back? The patent system guarantees insulation from competition for a substantial period of time so companies can recover the money the government

26. This is according to my own calculations. See Bryan Gardiner, Patently offensive, THE DAILY (Aug. 19, 2012), http://www.thedaily.com/article/2012/ 08/18/081812-tech-feature-apple-lawsuit-gardiner/ ("Lemley agrees. 'By my count, the companies litigating smartphone patents have spent about $\$ 700$ million in legal fees and $\$ 15$ billion buying patents to assert against each other,' he says.").

27. See Colleen V. Chien, Startups and Patent Trolls (Santa Clara Univ. School of Law, Accepted Paper No. 09-12, 2012), available at http://papers.ssrn.com/sol3/ papers.cfm?abstract_id=2146251 (finding that most troll suits are brought against small companies, not large ones).

28. See, e.g., JAMES BESSEN \& MiChAEL J. MEURER, PATENT FAILURE: HOW JUDGES, BUREAUCRATS, AND LAWYERS PUT INNOVATORS AT RISK 13 (2008) (finding that innovation works well only in the pharmaceutical industry); DAN L. BURK \& MARK A. LEMLEY, THE PATENT CRISIS AND HOW THE COURTS CAN SOLVE IT 3-4 (2009).

29. See Joseph A. DiMasi et al., The price of innovation: new estimates of drug development costs, 22 J. HEALTH ECON. 151, 166 (2003) (estimating the cost of a new drug to be $\$ 800$ million, unadjusted for inflation).

30. See, e.g., Benjamin N. Roin, Unpatentable Drugs and the Standards of Patentability, 87 TEX. L. REV. 503, 503 (2009); Eric Budish et al., Do fixed patent terms distort innovation? Evidence from cancer clinical trials (Oct. 21, 2012) (working paper) (on file with author). 
made them invest in the first place. And, unlike patents in other industries, which are enforced only by lawsuits against companies who make the decision to enter the market, the government itself prevents market entry by generics as long as there is a patent at stake. Once we take the health and safety regulatory system for granted-and that system might or might not be a good thing - we probably need a patent system like the current one. But it is far from ideal. Patents in the pharmaceutical industry are a second-order regulatory system. They are a government regulatory effort to limit market entry in the service of encouraging innovation that was discouraged by a different government regulation.

I should be clear: this is not an argument against IP altogether. IP can and does serve useful purposes. But we have seen a definite turn in IP enforcement away from common law adjudication of disputes and towards a regulatory state, in which the government either directly decides who can enter the market, or distributes so many rights to block entry to so many people that it is impractical to enter the market without advance permission. A "Mother, may I?" regime is not one calculated to encourage the sorts of disruptive innovations that have driven economic growth in this country for the last 150 years. Therein lies the problem. 